\title{
In reply: The criteria used to justify endotracheal intubation of patients with COVID-19 are worrisome
}

\author{
Danny J. N. Wong, MBBS, PhD, FRCA · Imran Ahmad, MBBS, \\ FRCA D J Jeyanjali Jeyarajah, MBBS, FRCA · Benjamin Vowles, MBBS, \\ FRCA · Sophie Ragbourne, MBBS - Ganeshkrishna Nair, MBBS, FRCA, EDRA • Kariem El-Boghdadly, MBBS, \\ MSc, FRCA
}

Received: 21 October 2020/Accepted: 21 October 2020/Published online: 10 November 2020

(C) Canadian Anesthesiologists' Society 2020

To the Editor,

We thank Dr. Tobin for his interest ${ }^{1}$ in our paper $^{2}$ and acknowledge his many years of clinical experience. The pandemic has certainly introduced many unknowns into clinical practice and the decision to implement a protocolized approach to the management of coronavirus disease (COVID-19) patients in our institution was not taken lightly. It was done so in the context of deep discussions within the multidisciplinary team in our institution considering the paucity of data at the early stages of the pandemic. In particular, there was no clear evidence at that time that advocating early or late intubation strategies was preferential.

We highlight the fact that the surge in patient numbers that we faced in London preceded that of North America, and that the cases we reported requiring tracheal intubation were only a fraction of the total burden of COVID-19 hospital admissions during this period. Despite this, the overall intensive care unit mortality in our institution was superior to national and international mortality estimates, ${ }^{\mathrm{A}, \mathrm{B}}$ suggesting that our management model did not have overt deleterious effects.

In addition, we noted the disease trajectory in some cases was associated with a rapid and steep decline, which if left unmanaged without mechanical ventilation, and

This reply is related to letter 20-01015. https://doi.org/10.1007/ s12630-020-01853-8.

D. J. N. Wong, MBBS, PhD, FRCA - I. Ahmad, MBBS, FRCA $(\bowtie) \cdot$ J. Jeyarajah, MBBS, FRCA - B. Vowles, MBBS, FRCA · S. Ragbourne, MBBS - G. Nair, MBBS, FRCA, EDRA · K. El-Boghdadly, MBBS, MSc, FRCA

Department of Anaesthesia, Guy's and St Thomas', NHS

Foundation Trust, London, UK

e-mail: drimranahmad1@gmail.com despite appropriate escalation of oxygen and other therapies, could result in physiologically difficult airways that would make the procedure of tracheal intubation significantly more hazardous.

We recognize with evolving understanding of this disease process that there are varied presentations of patients with COVID-19, and the theory that there are a number of phenotypes with differing pathophysiology and responsiveness to therapies. ${ }^{3}$ As experience grew, this was incorporated into treatment strategies and the escalation of care offered, but controversies continue relating to how best to approach non-uniform presentations of COVID-19. ${ }^{4}$

We agree with Dr. Tobin that tracheal intubation is not to be taken lightly, and the decision to intubate is not a trivial one, but also in reality must also be balanced with discussions relating to ethics and resource availability. Indeed, there remains a paucity of high-quality data to support or refute the early $v s$ late tracheal intubation models. Given the improvements in pharmacological wardlevel care of this disease, this debate remains underinvestigated. There is no right or wrong answer given the current evidence, nor was there at the time of conducting this study.

More research needs to be conducted to identify the best time to initiate mechanical ventilation, and delineate appropriate oxygen and ventilation strategies for these non-homogeneous presentations, and those patients that will be responsive to such therapies. ${ }^{5}$ Until then, however, we continue to support the notion that institutions should implement guidelines and standardized operating practices to minimize the inter-clinician variation in care within an institution, as unwarranted deviation is likely to introduce unnecessary confusion particularly in the context of safe care being delivered in surge areas, often across multiple sites and locations. 
Disclosures None.

\section{Funding statement None.}

Editorial responsibility This submission was handled by Dr. Hilary P. Grocott, Editor-in-Chief, Canadian Journal of Anesthesia.

\section{Footnotes}

A. Intensive Care National Audit \& Research Centre. ICNARC report on COVID-19 in critical care: England, Wales and Northern Ireland 16 October 2020. Available from URL: https://www.icnarc.org/Our-Audit/Audits/ Cmp/Reports (accessed October 2020).

B. Pritchard $M$, Dankwa EA, Hall M, et al. ISARIC Clinical Data Report: 4 October 2020. medRxiv 2020; DOI: https://doi.org/10.1101/2020.07.17.2015521.

\section{References}

1. Tobin MJ. The criteria used to justify endotracheal intubation of patients with COVID-19 are worrisome. Can J Anesth 2021. DOI: https://doi.org/10.1007/s12630-020-01853-8.

2. Ahmad I, Jeyarajah J, Nair G, et al. A prospective, observational, cohort study of airway management of patients with COVID-19 by specialist tracheal intubation teams. Can J Anesth 2020. DOI: https://doi.org/10.1007/s12630-020-01804-3.

3. Gattinoni L, Chiumello D, Caironi P, Busana M, Romitti $F$, et al. COVID-19 pneumonia: different respiratory treatment for different phenotypes? Intensive Care Med 2020; 46: 1099-102.

4. Matta SK. Dilemmas in Covid-19 respiratory distress: early vs late intubation; high tidal volume and low PEEP vs traditional approach? J Intensive Crit Care 2020. DOI: https://doi.org/10. 36648/2471-8505.6.2.7.

5. Camporota L, Vasques F, Sanderson B, Barrett NA, Gattinoni L. Identification of pathophysiological patterns for triage and respiratory support in COVID-19. Lancet Respir Med 2020; 8: 752-4.

Publisher's Note Springer Nature remains neutral with regard to jurisdictional claims in published maps and institutional affiliations. 